\title{
STRESSING FACTORS AND COPING STRATEGIES USED BY ONCOLOGY NURSES
}

\author{
Andrea Bezerra Rodrigues ${ }^{1}$ \\ Eliane Corrêa Chaves ${ }^{2}$
}

Rodrigues $A B$, Chaves $E C$. Stressing factors and coping strategies used by oncology nurses. Rev Latino-am Enfermagem 2008 janeiro-fevereiro; 16(1):24-28.

In the oncology specialty, many factors can result in occupational stress in nursing professionals. As an attempt to controlling this situation, individuals may use coping strategies. Coping is a cognitive and behavioral effort one uses to face a stressful situation. The aims of this study were to identify the stressful factors regarding oncology nurses, and to verify what coping strategies they use. Two questionnaires were used: a demographic data inventory, designed by the researcher, and the Folkman and Lazarus coping strategies inventory. The results showed that the main stressful factors for oncology nurses are patient death (28.6\%), emergency situations (16.9\%), relationship issues with the nursing team (15.5\%), and work-process situations (15.5\%). In the studied population, the main coping strategy used was positive reappraisal.

DESCRIPTORS: adaptation, psychological; nursing; stress; medical oncology

\section{FACTORES ESTRESANTES Y ESTRATEGIAS DE COPING UTILIZADAS POR LOS ENFERMEROS QUE ACTÚAN EN ONCOLOGÍA}

En la especialidad de Oncología son muchos los factores que pueden conducir al profesional de enfermería al estrés ocupacional. Para tratar de controlar esa situación, el individuo puede utilizar estrategias de coping, que es un esfuerzo cognitivo y de comportamiento utilizado frente a un evento que causa estrés. Los objetivos de este estudio fueron identificar los factores que causan estrés en los enfermeros que actúan en Oncología y verificar las estrategias de coping utilizadas por los mismos. Se utilizaron dos cuestionarios: uno para el inventario de datos demográficos construido por la autora y otro para el inventario de estrategias de coping de Folkman y Lazarus. Los resultados de la investigación muestran que los factores considerados más estresantes por los enfermeros de Oncología son: la muerte de los pacientes (28,6\%), las situaciones de emergencia (16,9\%), los problemas de relación dentro del equipo de enfermería $(15,5 \%)$ y las situaciones relacionadas al proceso de trabajo (15,5\%). En la población estudiada, la estrategia de coping más utilizada fue la de reevaluación positiva.

DESCRIPTORES: adaptación psicológica, enfermería; estrés; oncología médica

\section{FATORES ESTRESSANTES E ESTRATÉGIAS DE COPING DOS ENFERMEIROS ATUANTES EM ONCOLOGIA}

Na especialidade oncologia, são muitos os fatores que podem conduzir o profissional de enfermagem ao stress ocupacional. Para tentar controlar essa situação, o indivíduo pode utilizar estratégias de coping, que é um esforço cognitivo e comportamental utilizado frente a evento estressor. Os objetivos desse estudo foram identificar os fatores estressantes para enfermeiros que atuam em oncologia e verificar as estratégias de coping utilizadas pelos mesmos. Foram utilizados dois questionários: um inventário de dados demográficos, construído pela autora, e o inventário de estratégias de coping de Folkman e Lazarus. Os resultados da pesquisa mostram que os fatores considerados mais estressantes para os enfermeiros de oncologia são: o óbito dos pacientes (28,6\%), as situações de emergência (16,9\%), os problemas de relacionamento com a equipe de enfermagem (15,5\%) e as situações relacionadas ao processo de trabalho (15,5\%). Na população estudada, a estratégia de coping mais utilizada foi a reavaliação positiva.

DESCRITORES: adaptação psicológica; enfermagem; estresse; oncologia

${ }^{1}$ RN, Specialist in Oncology Nursing, Doctoral Student, University of São Paulo School of Nursing, Faculty, Hospital Israelita Albert Einstein School of Nursing, Brasil, email: andreabrodrigues@ig.com.br; ${ }^{2}$ RN, B.Sc. in Philosophy, Ph.D. in Psychology, Faculty, University of São Paulo School of Nursing, Brazil, e-mail: ecchaves@usp.br 


\section{INTRODUCTION}

Due to the complexity involved in caring for oncology patients, several studies have addressed the problems that the involved health care professionals have to face, especially concerning the nursing team.

Nursing practice in the oncology specialty requires greater mental control and activity compared to other areas, since it involves dealing with a serious disease, caring for terminal patients with no available treatment, the need for intensive and prolonged care, and becoming very close with the patient's family. Thus, these health care professionals experience emotional situations that can be quite wearisome, and such factors can cause occupational stress ${ }^{(1-3)}$.

In the attempt to control a stressful situation, individuals can use coping strategies. Coping is referred to as "a cognitive and behavioral effort one makes to take control over, tolerate, or reduce external and internal demands". According to those authors, every event is subject to a cognitive evaluation by the subject who experiences it. That evaluation is a process of categorizing an encounter, focused on its purpose or meaning ${ }^{(4)}$.

The form by which individuals choose their coping strategies is determined, in part, by their internal and external resources, which include health, beliefs, responsibility, support, social skills, and material resources.

From a cognitivist perspective, a model has been proposed, which divides coping in two functional categories: problem- focused coping, and emotion-focused coping. In the former, there is a search for strategies derived from defensive processes, like avoidance, moving away, and seeking positive values in negative events as a form of reducing the emotional relevance of the stressor. In problem-focused coping, on the other hand, one tries to define the problem, searching for alternative solutions and choosing among them ${ }^{(4)}$. There are eight coping factors: confrontation, self-control, social support, responsibility acceptance, escapeavoidance, problem solving, and positive reappraisal.

The aims of the present study are to identify the stressful factors for nurses working in oncology and verify what coping strategies they use.

\section{METHOD}

This is a descriptive-exploratory study using quantitative approach resources. The research was carried out in Oncology wards of five large-scale hospitals located in the city of Sao Paulo. The study population consisted of 77 nurses with at least one year of practice. To meet the objectives, selfadministered questionnaires were used. The first questionnaire is a demographic data inventory designed by the author, and the second is the Folkman and Lazarus Coping Strategies Inventory, adapted for the Portuguese language ${ }^{(5)}$.

The Folkman and Lazarus Coping Strategies Inventory contains 66 items about thoughts and actions that people use to deal with internal and external demands of a specific stressful event, besides 'distractive' questions that are not scored on the conversion scale. All questions are scored using the Likert scale, ranging from 0 - I did not use this strategy; 1 - I used it a little; 2 - I used it; 3 - I used it very much. The scale consists of eight different 'factors' suggested by the factorial analysis: confrontation, withdrawal, self-control, social support, responsibility acceptance, escapeavoidance, problem solving, and positive reappraisal.

The research was performed after being approved by the institutions' review boards, receiving authorization from the hospitals' managers, and obtaining written consent from all the participants.

The interviewees were asked to think about a professional situation they have experienced in a typical workweek, which caused worry and stress. The referred week had to be, specifically, the week before the interview. Next, the nurses filled out the Coping Strategies Inventory, in which they scored each phrase according to how they dealt with the situation they described in the beginning of the inventory.

After data collection, the information was stored in a data bank using MS Excel 2002. Cronbach Alpha Coefficient was used to verify the reliability of the research instruments. The instrument was considered reliable and with internal consistency for Cronbach Alpha values above 0.7. 


\section{RESULTS}

Table 1 - Distribution of oncology nurses according to gender, age group, marital status, being an oncology specialist, and choice to work in oncology. Sao Paulo, 2005

\begin{tabular}{|c|c|c|}
\hline Variable & $\mathbf{N}$ & $\%$ \\
\hline \multicolumn{3}{|c|}{ Gender } \\
\hline Male & 4 & 5.2 \\
\hline Female & 73 & 94.8 \\
\hline \multicolumn{3}{|c|}{ Age group (years) } \\
\hline 20 to 30 & 26 & 33.8 \\
\hline 31 to 40 & 39 & 50.6 \\
\hline 41 to 50 & 12 & 15.6 \\
\hline \multicolumn{3}{|c|}{ Marital Status } \\
\hline Married & 33 & 42.9 \\
\hline Single (no partner) & 31 & 40.3 \\
\hline Single (with partner) & 10 & 12.9 \\
\hline Divorced & 3 & 3.9 \\
\hline \multicolumn{3}{|c|}{ Oncology Specialist } \\
\hline Yes & 23 & 29.9 \\
\hline No & 54 & 70.1 \\
\hline \multicolumn{3}{|c|}{ Chose to work in oncology } \\
\hline Yes & 56 & 72.7 \\
\hline No & 21 & 27.3 \\
\hline
\end{tabular}

It is noticed that the population is mainly composed of women $(94.8 \%)$, in the age group 31 40 years $(50.6 \%)$. The prevalent marital status is married (42.9\%). Most participants are not oncology specialists $(70.1 \%)$, and they chose to work in oncology $(72.7 \%)$.

Table 2 - Cronbach alpha reliability coefficient for the coping factors. São Paulo, 2005

\begin{tabular}{lcc}
\hline \multicolumn{1}{c}{ Factors } & Number of items & Cronbach Alpha \\
\hline F1 (Confrontation) & 6 & 0.541 \\
F2 (Withdrawal) & 6 & 0.556 \\
F3 (Self-control) & 7 & 0.617 \\
F4 (Social support) & 6 & 0.530 \\
F5 (Responsibility acceptance) & 4 & 0.610 \\
F6 (Escape-avoidance) & 8 & 0.727 \\
F7 (Problem solving) & 6 & 0.732 \\
F8 (Positive reappraisal) & 7 & 0.752 \\
\hline
\end{tabular}

Cronbach alpha values above 0.70 were considered appropriate. In this analysis, Cronbach alpha values were appropriate for the following factors: escape-avoidance (0.727), problem solving $(0.732)$, and positive reappraisal $(0.752)$, as observed in Table 2.
Table 3 - Distribution of oncology nurses according to the stressful situation which they had to cope with. Sao Paulo, 2005

\begin{tabular}{|c|c|c|}
\hline Stressful Situation & $\mathbf{N}$ & $\%$ \\
\hline Death & 22 & 28.6 \\
\hline Emergency & 13 & 16.9 \\
\hline Relationship with the nursing team & 13 & 16.9 \\
\hline Work Process & 12 & 15.5 \\
\hline Relationship with the patient or family & 10 & 13.0 \\
\hline Relationship with the physician & 7 & 9.1 \\
\hline Total & 77 & 100 \\
\hline
\end{tabular}

Table 3 outlines the stressful situation described by the nurses, the number of nurses that perceive that situation as a stressor, and the respective percentage.

The main stressful situations that mobilize the nurses toward coping are patient death (28.6\%), emergency situations (16.9\%), relationship issues with the nursing team (16.9\%), and work-process situations $(15.5 \%)$.

Among the emergency situations, the nurses reported cardiorespiratory arrest, anaphylactic reactions during the use of chemotherapeutics, and cases when the patients' condition worsens. Regarding the issues involving the nursing team, the nurses reported situations of arguments about some of his or her conducts that were not accepted by the team, and how the work shifts were determined.

Table 4 - Distribution of the scores for coping factors presented by the nurses. São Paulo, 2005

\begin{tabular}{lccccc}
\hline \multicolumn{1}{c}{ Coping Factors } & N & Minimum & Maximum & Mean & $\begin{array}{c}\text { Standard } \\
\text { Deviation }\end{array}$ \\
\hline Confrontation & 77 & 0 & 14 & 6.01 & 3.235 \\
Withdrawal & 77 & 0 & 15 & 6.26 & 3.091 \\
Self-control & 77 & 0 & 18 & 9.86 & 3.979 \\
Social support & 77 & 0 & 17 & 8.76 & 3.179 \\
Responsibility acceptance & 77 & 0 & 9 & 3.71 & 2.682 \\
Escape-avoidance & 77 & 0 & 18 & 6.07 & 4.620 \\
Problem solving & 77 & 2 & 18 & 9.91 & 3.947 \\
Positive reappraisal & 77 & 0 & 20 & 10.34 & 4.960 \\
\hline
\end{tabular}

It is observed that the coping strategy most used by the nurses is positive reappraisal (10.34), followed by problem solving (9.91), and self-control (9.86). However, in this study, the self-control strategy did not show an appropriate Cronbach Alpha value (0.617). The least used coping strategy is responsibility acceptance. 


\section{DISCUSSION}

Oncology is a field full of particularities that are often unknown by nurses, because they usually do not receive any specific training in the field, since most Brazilian universities do not approach cancerology in the nursing undergraduate course.

Therefore, the 'true' choice for working in oncology can occur after some professional experience in the field. This was observed in the study by Ramalho, performed with nurses who worked in a specialized hospital for children with cancer, in Sao Paulo. The nurses reported they feel special and have divine protection to deal with 'failure' as a challenge ${ }^{(6)}$.

Though most nurses $(72.7 \%)$ chose the specialty, $70.1 \%$ do not have specific training in oncology. This data is relevant because the specialty implies several venous devices that are very specific, particular protocols for each type of cancer, and treatments like radiotherapy, chemotherapy, and immunotherapy, which demand specific knowledge. In most Brazilian universities, nursing undergraduate course curricula do not include these subjects. For this reason, professionals who wish to work in the field search for specialization as soon as they complete their undergraduate course. However, that was not observed in this study.

In this study, most nurses working in oncology do not have any specific training in the field. These nurses probably acquired their knowledge while developing their functions at work. It should be considered that these professionals have worked in oncology for an average of 72.7 months, so it would be expected that there would be more oncology specialist nurses.

The nurses in this study reported that the situations that most generated stress at work were patient death (28.6\%), emergency situations (16.9\%), relationship issues with the nursing team (15.5\%), and work-process situations (15.5\%).

Similar to this study, others have reported situations that nurses commonly realize as being stressful, such as the relationship with patients without any treatment possibilities, patient death, unexpected and new situations, inadequate preparation for the role they have to perform, interpersonal conflicts, personnel shortage, the delay to receive medical care, and excessive workload $^{(7-9)}$.

Among the death situations reported by the nurses, special emphasis was given to deaths of children and adolescents. Six (27.2\%) of the 20 nurses reported these situations, and two nurses stated they felt stressed with that death. The death of a child or adolescent is interpreted as the interruption of their biological cycle, and can cause feelings of helplessness, frustration, sadness, and distress in the health care team ${ }^{(10)}$.

The referred relationship issues, whether intradisciplinary, interdisciplinary, or with patients and their relatives is worrisome because it permeates every activity that nurses perform, concerning either health care or management.

The activity of exchanging experiences, which could provide a means for identification and reflection about the professional practice in oncology, could be hindered by the intra and interdisciplinary relationships referred by the nurses.

All these factors, considered stressful for nurses who work in oncology, should be considered potential triggers of burn out, a syndrome characterized by emotional distress, despersonalization, and feelings of professional incompetence, which could even cause the nurse to abandon the specialty. Specifically in oncology, this is a very negative repercussion since there is a scarcity of specialist nurses.

One concern regarding the consequences of burn out is the perception that patients have about the quality of the care they are receiving. This factor has been researched and reported in a study performed with 711 nurses. The study associated developing burn out with the satisfaction of the care they provided to 605 patients hospitalized in 16 different hospital units. In units where nurses presented emotional distress and despersonalization, the patients reported to be less satisfied with the quality of the care they received ${ }^{(11)}$.

Coping could be a form to avoid occupational stress. However, the studied population mostly uses the emotion-focused coping, mainly the positive reappraisal strategy. In this strategy, the person tries to restructure the event with the aim to find aspects that favor the event in some way. The person may also talk to him/herself trying to reduce the severity of the situation, and focus on the positive aspects of the situation, as a way to reduce the emotional load of the event, in the attempt to change the situation.

Another strategy used was the problemfocused coping, i.e., problem solving. Some authors refer that certain types of coping are more useful than others, and emphasize that problem-focused coping can reduce stress ${ }^{(12)}$. 
Some coping subscales, for example responsibility acceptance and self-control, presented low reliability for the studied population according to Cronbach Alpha. These values range according to the population, and it is worth emphasizing that coping strategies can be learned.

Actually, there is no right or wrong coping strategy. Coping strategies are either effective or ineffective. Choosing a coping strategy is something quite personal. While relaxation techniques work well for some people, for others it can be rather stressful. For this reason, respecting personal characteristics is very important.
Further studies should be developed with nurses working in oncology in order to evaluate the correlations between coping strategies and variables like personality, previous experiences, and social support, factors that are implied in the use of coping strategies.

This study shows that the most stressful situations for the studied sample are patient death $(28.6 \%)$, emergency situations $(16.9 \%)$, relationship issues with the nursing team (15.5\%), and workprocess situations $(15.5 \%)$. The studied population used emotion-focused coping the most, mainly positive reappraisal.

\section{REFERENCES}

1. Chacón Roger M, Grau Abalo J. Burn out em enfermeros que brindan atención a pacientes oncológicos. Rev Cuba oncol 1997; 13(2):118-25.

2. Penson RT, Dignan FL, Canellos GP, Picard CL, Lynch TJ. Burn out: Caring for the caregivers. Oncologist 2000; (5):425-34.

3. Medland J, Howard-Ruben J, Whitaker E. Fostering psychosocial wellness in oncology nurses: addressing burn out and social support in the workplace. Oncol Nurs Forum 2004; 31(1):47-54.

4. Folkman S, Lazarus RS. Personal control and stress and coping processes: A theoretical analysis. Personality and Social Psychol 1984; 46:839-52.

5. Savóia MG, Santana PR, Mejias NP. Adaptação do inventário de estratégias de coping de Folkman e Lazarus para o português. Psicologia USP 1996; 7(1/2):183-201.

6. Ramalho MAN. Conhecendo as vivências dos cuidadores: estudo exploratório com profissionais da área de oncologia pediátrica. [dissertação]. São Paulo (SP): Escola de Ciências da Secretaria de Estado da Saúde de São Paulo; 2005.

7. Dewe JP. Identifying the causes on nurses stress: a survey of New Zeland nurses. Work Stress 1983; 1(1):15-24.

8. Barros ALBL, Humerez DC, Fakih FT, Michel JLM. Situações geradoras de ansiedade e estratégias para seu controle entre enfermeiras: estudo preliminar. Rev Latino-am Enfermagem 2003 setembro-outubro; 11(5):585-92.

9. Mendes AM, Linhares NJR. A prática do enfermeiro com pacientes da UTI: uma abordagem psicodinâmica. Rev Bras Enferm 1996; 49:267-80.

10. Spíndola T, Macedo MCS. A morte no hospital e seu significado para os profissionais. Rev Bras Enferm 1994; 47(2): 108-17.

11. Leiter MP, Harvie P, Frizzell C. The correspondence of patient satisfaction and nurse burn out. Soc Sci 1998; 47(10):1611-17.

12. Jones MC, Johnston DW. Distress, stress and coping in first year student nurses. J Adv Nurs 1997; 26:475-82. 